J. Clin. Chem. Clin. Biochem.

Vol. 14, 1976, pp. 453-458

\title{
Critical Evaluation of Measurement of Platelet Monoamine Oxidase in Man $^{1}$ )
}

\author{
By H. Honecker, W. Christ, B. Müller-Oerlinghausen and H. Coper \\ Institute of Neuropsychopharmacology, Free University Berlin
}

(Received March 23/May 28, 1976)

Summary: Some biochemical characteristics such as substrate specificity, substrate affinity and inhibitor sensitivity of monoamine oxidase of human blood platelets were investigated. Tyramine, tryptamine and $\beta$-phenylethylamine were used as substrates. The apparent Michaelis constants, maximal velocity rates and $\mathrm{I}_{\mathbf{5 0}}$ for the inhibitor tranylcypromine were determined. The data were analyzed according to Lineweaver-Burk and Dixon.

The influence of amitriptyline, a prototype of tricyclic antidepressants, on the selected variables $\left(K_{\mathrm{m}}, V, \mathrm{I}_{50}\right)$, was studied.

The parameters investigated showed remarkably low interindividual differences when healthy volunteers were tested.

The inhibitor activity of amitriptyline towards platelet monoamine oxidase depends on the substrate used. Amitriptyline concentrations which showed a pronounced effect on the enzyme characteristics are significantly higher than plasma levels of the drug found under therapeutic conditions.

\section{Kritische Überprïfung der Bestimmung von Monoamin-oxidase in Thrombocyten des Menschen}

Zusammenfassung: Einige biochemische Charakteristika wie Substrat-Spezifität, Substrat-Affinität und InhibitorSensitivität der Monoaminoxidase aus menschlichen Thrombocyten wurden untersucht. Als Substrate dienten Tyramin, Tryptamin und $\beta$-Phenylethylamin. Bestimmt wurden die Michaelis-Konstanten, die maximalen Umsatzgeschwindigkeiten sowie die Tranylcypromin-Konzentration, die eine 50\%ige Hemmung der oxidativen Desaminierung verursacht. Die Meßdaten wurden mit Hilfe von Lineweaver-Burk- und Dixon-Diagrammen ausgewertet. Am Beispiel des Amitriptylins wurde untersucht, inwieweit tricyclische Psychopharmaka die Monoaminoxidase hemmen und die gewählten Chạakteristika beeinflussen kọnnen.

Alle untersuchten Parameter $\left(K_{\mathrm{m}}, V, \mathrm{I}_{50}\right)$ zeigten bemerkenswert geringe interindividuelle Unterschiede bei Bestimmungen an gesunden Kontrollpersonen.

Amitriptylin hemmt die Monoaminoxidase in Abhängigkeit vom eingesetzten Substrat. Die Amitriptylin-Konzentration, die einen deutlichen Einfluß auf die gewählten Enžymcharakteristika ausübt, liegt etwa eine Zehnerpotenz über den Plasmakonzentrationen des Pharmakons, die üblicherweise unter therapeutischen Bedingungen gefunden werden.

\section{Introduction}

The substrate specificity and inhibitor sensitivity of monoamine oxidase (monoamine: $\mathrm{O}_{2}$ oxidoreductase (deaminating) EC 1.4.3.4) of human blood platelets are similar to those of monoamine oxidase type $B$ from human brain $(1-4)$. Since some abnormalities in the metabolism of biogenic amines in patients with mental disorders have been postulated $(5,6)$ several investigators have tried to correlate the activity of the platelet monoamine oxidase with the symptomatology and classification of mental diseases, thereby implying that a change of platelet monoamine oxidase may reflect an alteration of brain monoamine oxidase activity. Murphy et al $(7,8)$ using tryptamine found that platelet monoamine oxidase activity was reduced in chronic schizophrenics as well as in bipolar depressed patients. Nies et al (9), using benzylamine as substrate, reported

1) A preliminary report of this study was presented at the 1 st European Neurosciences Meeting, Munich, September 28, 1975 . 
an increased platelet monoamine oxidase activity during depression in schizophrenic patients. However, Friedman et al (10) and also Shaskan \& Becker (11) could not detect any alteration in monoamine oxidase activity in psychiatric patients. Most studies hitherto refer to the activity of the enzyme at a single substrate concentration only, whereas enzymic kinetic constants e.g. maximal velocity rate $(V)$ and Michaelis constant $\left(K_{\mathrm{m}}\right)$ have rarely been published. Data on substrate specificity, substrate affinity and inhibitor characteristics determined simultaneously are not available. According to our working hypothesis, some properties of monoamine oxidase and other enzymes involved in the metabolic pathway of biogenic amines might be altered in patients with manic depressive disorders. It is therefore necessary to determine $K_{\mathrm{m}}, V$ and $\mathrm{I}_{50}$ simultaneously. Thus a differentiated method is required which can be used under clinical routine conditions.

Evidence for the existence of isoenzymes of monoamine oxidase $B$ is very weak (12). On the other hand, there is evidence that the enzyme has several catalytic sites (13). We therefore used three different substrates, tyramine, tryptamine and phenylethylamine.

Tricyclics appear to influence the enzyme activity in vitro under special experimental conditions $(8,13,14)$. The effect of trycyclic antidepressive drugs on the kinetic parameters of platelet monoamine oxidase was therefore also examined.

\section{Methods}

Preparation of platelet rich plasma

Blood samples were collected at $9 \mathrm{a}$. $\mathrm{m}$. by dropping venous blood (ca. $25 \mathrm{ml}$ ) from the cannula into plastic tubes containing $5 \mathrm{ml}$ of ACD-stabilizer (USPx VIII formula B) as the anticoagulant. The samples were centrifuged for 30 minutes at $180 \mathrm{~g}$ at $25^{\circ} \mathrm{C}$. A constant aliquot of platelet rich plasma $(10 \mathrm{ml})$ was removed, using a plastic syringe. Thereafter the number of platelets was counted. Aliquots of $0.2 \mathrm{ml}$ platelet rich plasma were added to $1.0 \mathrm{ml}$ of phosphate buffer $(0.1 \mathrm{~mol} / 1 ; \mathrm{pH} 7.4)$. These platelet rich plasma buffer mixtures are stored at $-20^{\circ} \mathrm{C}$ and used directly for monoamine oxidase determinations. Under these conditions no loss in monoamine oxidase activity could be detected within four weeks. Monoamine oxidase activities are expressed as nanomoles of deaminated products formed per $10^{8}$ of platelets per hour.

\section{Materials}

Tyramine hydrochloride and tryptamine hydrochloride were obtained from EGA-Chemie, Steinheim; $\beta$-phenylethylamine and serotonin-creatininsulfate from Merck, Darmstadt; trans2-phenylcyclopropylamine hydrochloride (Tranylcypromine) from Sigma; $\left[1-{ }^{14} \mathrm{C}\right]$ tyramine hydrochloride $9.2 \mathrm{Ci} / \mathrm{mol}$, [sidechain $2-{ }^{4} \mathrm{C}$ ]tryptamine bisuccinate $53 \mathrm{Ci} / \mathrm{mol}, 5$-hydroxytryptamine binoxolate $\left(\left[2-{ }^{14} \mathrm{C}\right]\right.$ serotonin binoxolate $), 48 \mathrm{Ci} / \mathrm{mol}$ and $\left[{ }^{14} \mathrm{C}\right] \beta$-phenylethylamine hydrochloride $9.86 \mathrm{Ci} / \mathrm{mol}$, from NEN, Dreieichenhain, amitriptyline hydrochloride (5-(3-dimethylamino-propyliden)-dibenzo[a, d][1,4]cycloheptadiene $\mathrm{HCl}$ ) was a gift from Sharp and Dohme, Munich.
Assay procedure of monoamine oxidase with tyramine, tryptamine and $\beta$-phenylethylamine as substrates

a) The standard assay contained in a final volume of $2.0 \mathrm{ml}$ : platelet rich plasma/buffer mixture $1.2 \mathrm{ml}$; tyramine $0.02-0.1 \mathrm{ml}$ (corresponding to $10 \mu \mathrm{mol} / 1$ to $50 \mu \mathrm{mol} / \mathrm{l}) ; 0.05 \mathrm{ml}\left[{ }^{14} \mathrm{C}\right.$ ] tyramine ( $50 \mathrm{nCi}$, corresponding to $2.7 \mu \mathrm{mol} / 1)$;

tryptamine $0.025-0.1 \mathrm{ml}$ (corresponding to $2.5 \mu \mathrm{mol} / 1$ to

$\left.25.5 \mu \mathrm{mol} / \mathrm{l}) ; 0.05 \mathrm{ml} \mathrm{[}{ }^{14} \mathrm{C}\right]$ tryptamine (50 $\mathrm{nCi}$, corresponding to $0.5 \mu \mathrm{mol} / \mathrm{l}$ );

B-phenylethylamine $0.015 \mathrm{ml}-0.05 \mathrm{ml}(15 \mathrm{nCi}$ to $50 \mathrm{nCi}$, corresponding to $0.7 \mu \mathrm{mol} / 1$ to $2.5 \mu \mathrm{mol} / 1$ );

serotonin $0.01-0.1 \mathrm{ml}$ (corresponding to $10 \mu \mathrm{mol} / 1$ to

$\left.100 \mu \mathrm{mol} / \mathrm{l}) ; 0.05 \mathrm{ml} \mathrm{[}{ }^{14} \mathrm{C}\right]$ serotonin (50 $\mathrm{nCi}$, corresponding to $0.51 \mu \mathrm{mol} / \mathrm{l}$ );

phosphate buffer $0.1 \mathrm{~mol} / \mathrm{l}$; $\mathrm{pH} 7.4$.

Samples were incubated in plastic tubes for $30 \mathrm{~min}$ (tyramine, tryptamine, serotonin), or for $20 \mathrm{~min}$ (phenylethylamine) at

$37^{\circ} \mathrm{C}$ in a Dubnoff shaker under air. The reaction was stopped by the addition of $0.25 \mathrm{ml}$ of $4 \mathrm{~mol} / 1 \mathrm{HCl}$. The mixture was transferred to $10 \mathrm{ml}$ glass stoppered centrifuge tubes containing $5 \mathrm{ml}$ of a toluene/ethyl acetate mixture (volumes, $2.5 \mathrm{ml}$ $+2.5 \mathrm{ml}$ ). The samples were shaken for 10 minutes in a mechanical shaker. After centrifugation a $3.0 \mathrm{ml}$ aliquot of the supernatant fluid was transferred to a scintillation counting vial containing $10 \mathrm{ml}$ of a toluene scintillation cocktail. The radioactivity of samples was determined by liquid scintillation spectroscopy in a Packard liquid scintillation counter at an efficiency for ${ }^{14} \mathrm{C}$ of $90 \%$. Blanks were obtained from each determination by adding $\mathrm{HCl}$ to the assay mixture prior to the incubation.

Protein concentrations were measured by the method of Lowry et al (15). In control experiments it was established that platelet free plasma did not contain noteworthy monoamine oxidase activity towards the substrates mentioned.

b) For the evaluation of $I_{50}$ the samples were preincubated for $10 \mathrm{~min}$ at $37^{\circ} \mathrm{C}$ at four different inhibitor concentrations (tranylcypromine from $0.02 \mu \mathrm{mol} / 1$ to $0.15 \mu \mathrm{mol} / \mathrm{l}$ ). Thereafter the enzyme activity was determined using constant substrate concentrations: tyramine $27.7 \mu \mathrm{mol} / 1$; tryptamine $10.5 \mu \mathrm{mol} / 1 ; \beta$-phenylethylamine $2.5 \mu \mathrm{mol} / 1$.

c) In order to determine the influence of amitriptyline on the $K_{\mathrm{m}}$ and $V$ values of the different substrates, the platelet samples were preincubated for $10 \mathrm{~min}$ at $37^{\circ} \mathrm{C}$ with different concentrations according to the standard assay a.

To study the influence of amitriptyline on the $I_{50}$ of tranylcypromine, the preincubation was performed in the presence of amitriptyline $(1 \mu \mathrm{mol} / \mathrm{l} ; 10 \mu \mathrm{mol} / \mathrm{l})$ and tranylcypromine, after which the procedure was continued according to $b$.

The Michaelis constant $\left(K_{\mathrm{m}}\right)$ and the maximal velocity rate (V) were calculated by a Lineweaver-Burk diagram, the $50 \%$ inhibition $\left(\mathrm{I}_{50}\right)$ was also determined graphically by interpolation from curves of percentage inhibition against pI.

\section{Results}

Serotonin $(10 \mu \mathrm{mol} / \mathrm{l})$, which is a good substrate for monoamine oxidase $A$, showed very low rate of oxidation with platelet monoamine oxidase, amounting to 1 to $2 \%$ of that with tryptamine.

As we used platelet rich plasma as the enzyme source, benzylamine was not used as a substrate, because it shows a high rate of oxidation by serum amine oxidase. In agreement with previous studies $(12,13)$ monoamine oxidase activity was found to be linear in LineweaverBurk plots (16) for tyramine and tryptamine between 
$1 \mu \mathrm{mol} / 1$ and $100 \mu \mathrm{mol} / 1$. With phenylethylamine, however, substrate inhibition occurs at molar concentrations higher than $10 \mu \mathrm{mol} / 1$ (fig. 1). Therefore, the kinetics of phenylethylamine must be determined with substrate concentrations that give a linear Lineweaver-Burk plot. Linearity was obtained even when more than $10 \%$ of the substrate was converted to product; i. e. under conditions for which the Michaelis Menten equation is not correctly fulfilled.

Figure 2 shows that the mechanism of monoamine oxidase inhibition by tranylcypromine is the same for tyramine, tryptamine, and phenylethylamine respectively. However, the Dixon plot (17) usually taken

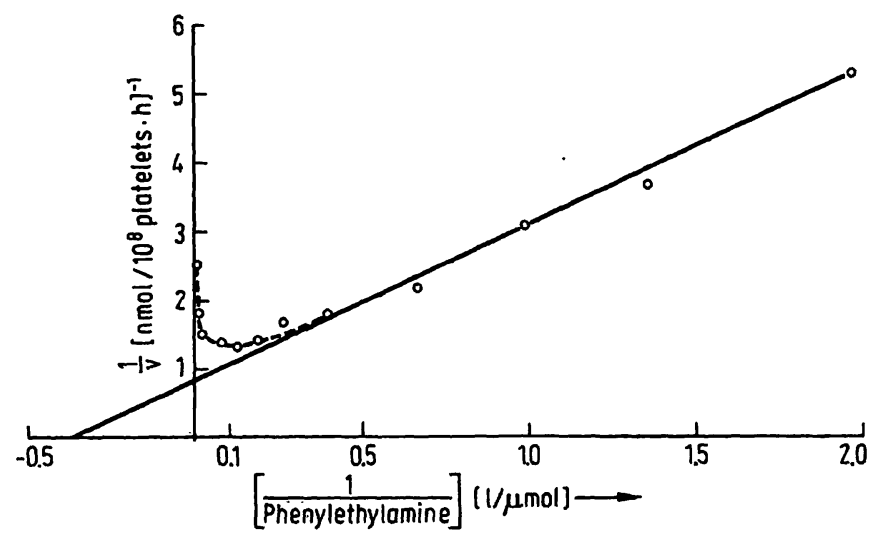

Fig. 1. Lineweaver-Burk plot of deamination of $\beta$-phenylethylamine by platelet monoamine oxidase. Experimental details are presented in Methods.

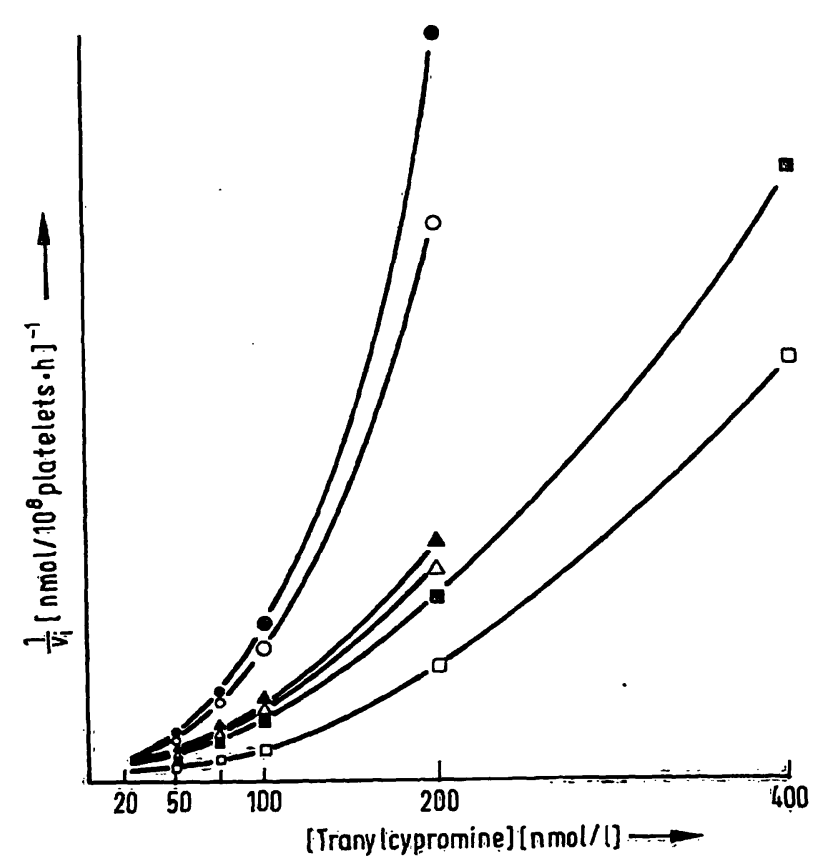

Fig. 2. Dixon plot for the inhibition of platelet monoamine oxidase by varying amounts of tranylcy promine using tyramine, tryptamine and $\beta$-phenylethylamine as substrates. Tyramine $5.3 \mu \mathrm{mol} / 1(\bullet-\infty)$ and $7.7 \mu \mathrm{mol} / 1$ $(0-0)$ tryptamine $1.0 \mu \mathrm{mol} / 1(\Delta-\Delta)$ and $1.5 \mu \mathrm{mol} / \mathrm{l}$ $(\Delta-\Delta) \beta$-phenylethylamine $1.0 \mu \mathrm{mol} / 1(-\square)$ and $2.5 \mu \mathrm{mol} / 1(0-0)$ incubation in the presence of varying amounts of tranylcypromine. Experimental details are presented in Methods. for the determination of the inhibition constant $K_{\mathrm{i}}$ does not yield straight lines but hyperbolic ones. From such inhibition curves the $K_{\mathrm{i}}$ value cannot be graphically determined. Therefore it is better to take the fifty percent inhibition $\mathrm{I}_{\mathbf{5 0}}$ as an inhibitor parameter.

As can be seen from figure 3 there is no great difference in the tranylcypromine inhibition curves and the $I_{50}$ of the three substrates for the platelet monoamine oxidase of healthy persons. Lineweaver-Burk plots for platelet monoamine oxidase activity obtained with blood samples from seven heal thy persons (24-49 years) using tyramine as substrate are shown in figure 4. This diagram demon-

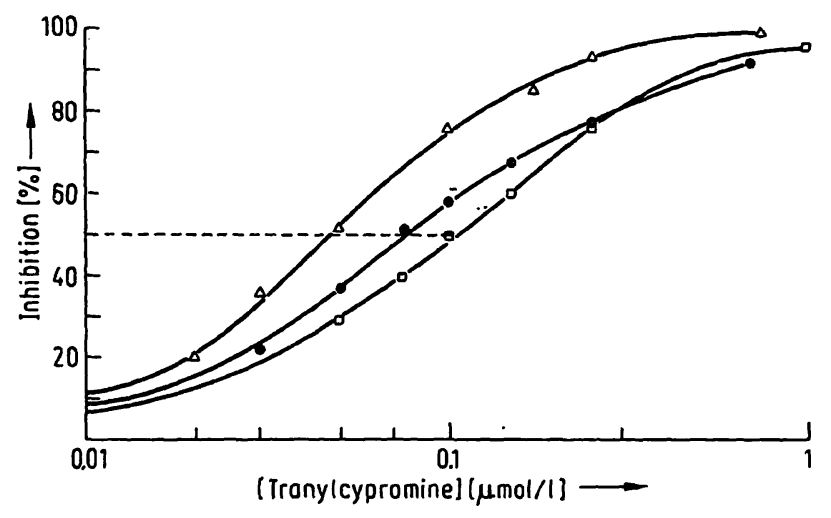

Fig. 3. Inhibition of platelet monoamine oxidase by tranylcypromine when the substrates tyramine $(\Delta-\Delta)$, tryptamine $(\bullet-\bullet)$ and $\beta$-phenylethylamine $(\square-0)$ were used. Experimental details are presented in Methods.

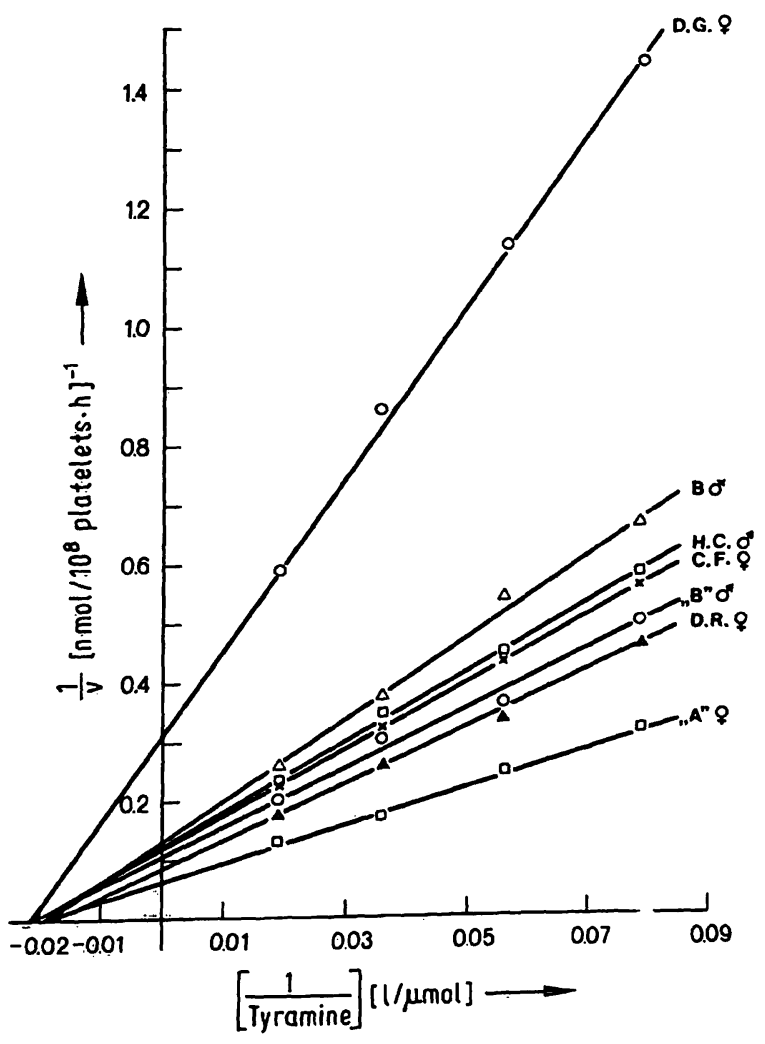

Fig. 4. Lineweaver-Burk plot of deamination of tyramine by platelet monoamine oxidase from different healthy persons. The assay conditions used were the same as described in Methods. 
Tab. 1. Enzyme characteristics of platelet monoamine oxidase in healthy persons $(n=14)$.

\begin{tabular}{|c|c|c|c|}
\hline & $\begin{array}{l}K_{\mathrm{m}} \\
{[\mu \mathrm{mol} / 1]} \\
\overline{\mathrm{x}} \pm \mathrm{s}\end{array}$ & $\begin{array}{l}V \\
\text { [nmol } / 10^{8} \\
\text { platelets } \cdot h] \\
\bar{x} \pm s\end{array}$ & $\begin{array}{l}\text { I }_{\text {so }} \\
\text { (tranyl- } \\
\text { cypromine) } \\
\text { [nmol/1] } \\
\bar{X} \pm s\end{array}$ \\
\hline $\begin{array}{l}\text { tyramine } \\
\text { tryptamine } \\
\text { phenylethylamine }\end{array}$ & $\begin{aligned} 59 & \pm 10 \\
7.4 & \pm 1.7 \\
1 & \pm 0.35\end{aligned}$ & $\begin{array}{l}8.9 \pm 2.0 \\
1.1 \pm 0.3 \\
5.2 \pm 2.8\end{array}$ & $\begin{array}{l}50 \pm 19 \\
62 \pm 20 \\
70 \pm 25\end{array}$ \\
\hline
\end{tabular}

Age \pm S. D. of normal control subjects:

men $(n=6): 35.3 \pm 7$ (from 29 to 49 years)

women $(n=8): 31.5 \pm 7.5$ (from 24 to 49 years)

strates the small interindividual variation of $K_{\mathrm{m}}$-values even in platelet samples having low enzyme activity.

The table presents $V, K_{\mathrm{m}}$ and $\mathrm{I}_{50}$ values obtained with the platelet monoamine oxidase of 14 healthy persons (male and female). The $K_{\mathrm{m}}$ values are in good agreement with those reported by other groups $(10,12,13)$. The reference system for $V$ is nanomol of deaminated product per $10^{8}$ platelets. No sex differences of monoamine oxidase activity could be found in this small group. The standard deviation in interindividual values is remarkably low.

Amitriptyline has a marked influence on the Michaelis constants and on the $V$ values of all three substrates only when the concentration is higher than $10 \mu \mathrm{mol} / 1$ (fig. 5,

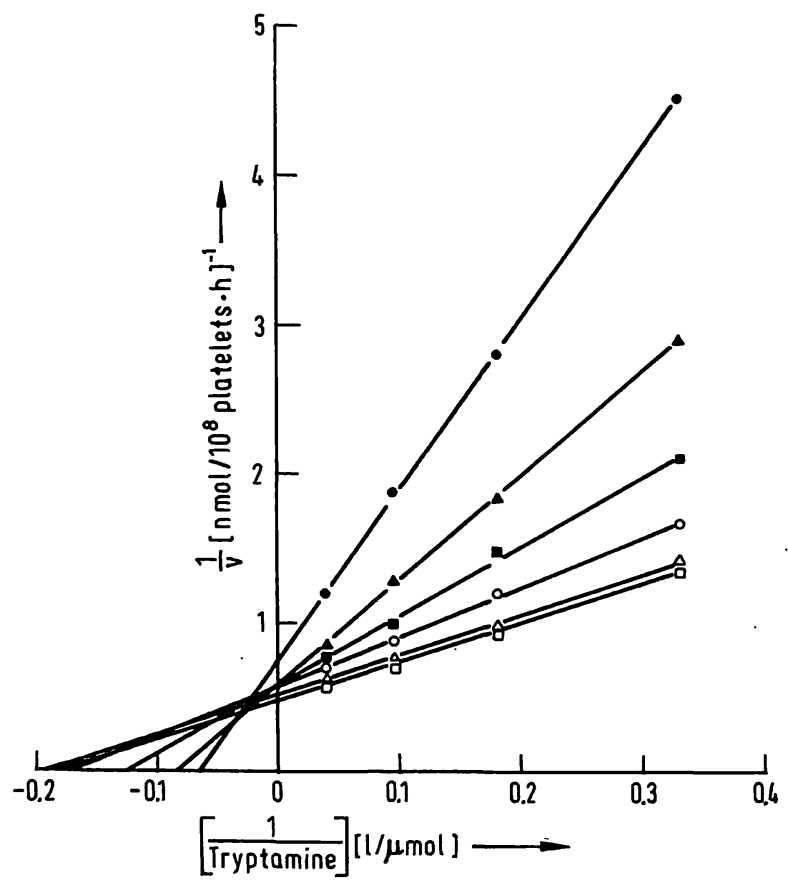

Fig. 6. Lineweaver-Burk plot for the inhibition of platelet monoamine oxidase by varying amounts of amitriptyline using tryptamine as substrate. Experimental details are presented in Methods.

Without amitriptyline $(0-0)$

Amitriptyline $1 \mu \mathrm{mol} / 1(\Delta-\Delta)$

$5 \mu \mathrm{mol} / 1(0-\infty)$

$10 \mu \mathrm{mol} / 1(\mathbf{m}-\mathrm{a})$

$20 \mu \mathrm{mol} / 1(\Delta-\Delta)$

$50 \mu \mathrm{mol} / \mathrm{l}(\bullet-\bullet)$
6, 7). But the monoamine oxidase inhibition caused by tranylcypromine is increased by lower concentrations of the antidepressive drug. Thereby the $I_{50}$ falls by half at an amitriptyline concentration of about $10 \mu \mathrm{mol} / 1$. However, this additional inhibition is more distinct in the presence of lower concentrations of tranylcypromine e. g. $40 \mathrm{nmol} / \mathrm{l}$ compared with $75 \mathrm{nmol} / \mathrm{l}$ (fig. 8).

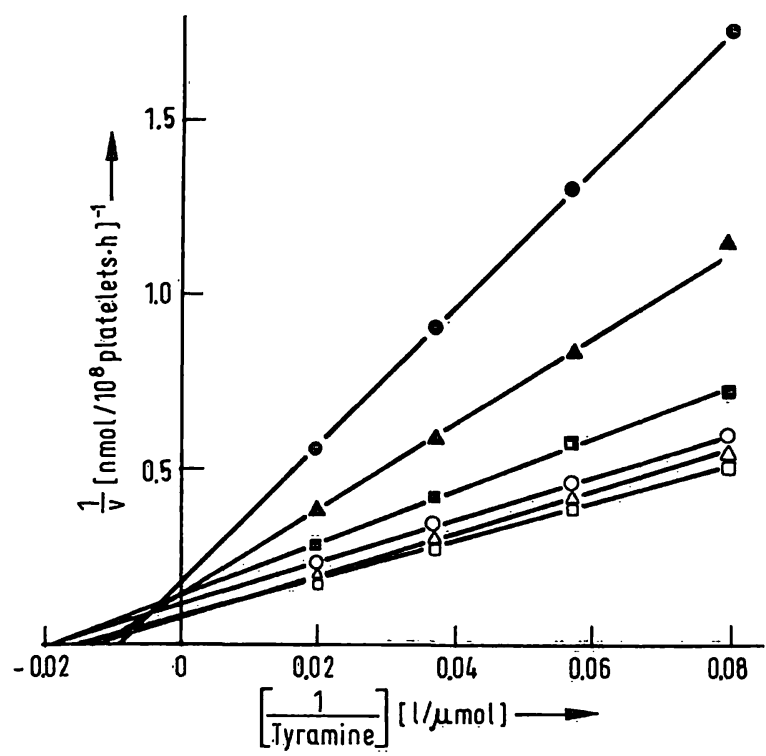

Fig. 5. Lineweaver-Burk plot for the inhibition of platelet monoamine oxidase by varying amounts of amitriptyline using tyramine as substrate. Experimental details are presented in Methods.

Without amitriptyline $(\square-0)$

Amitriptyline $1 \mu \mathrm{mol} / 1(\Delta-\Delta)$

$5 \mu \mathrm{mol} / 1(0-0)$

$10 \mu \mathrm{mol} / 1(\square-\square)$

$25 \mu \mathrm{mol} / 1(\Delta-\Delta)$

$50 \mu \mathrm{mol} / 1(\bullet-\bullet)$

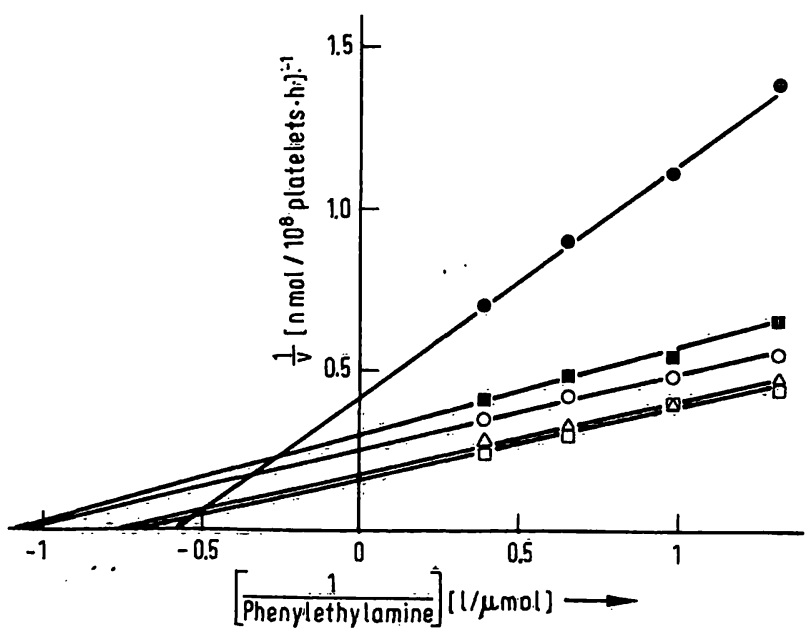

Fig. 7. Lineweaver-Burk plot for the inhibition of platelet monoamine oxidase by varying amounts of amitriptyline using $\beta$-phenylethylamine as suibstrate. Experimental details are presented in Methods.

Without amitriptyline $(a-\square)$

Amitriptyline $1 \mu \mathrm{mol} / 1(\Delta-\Delta)$

$5 \mu \mathrm{mol} / \mathrm{l}(\mathrm{O}-\mathrm{O})$

$10 \mu \mathrm{mol} / 1(-\infty)$

$50 \mu \mathrm{mol} / 1(\bullet-\bullet)$ 

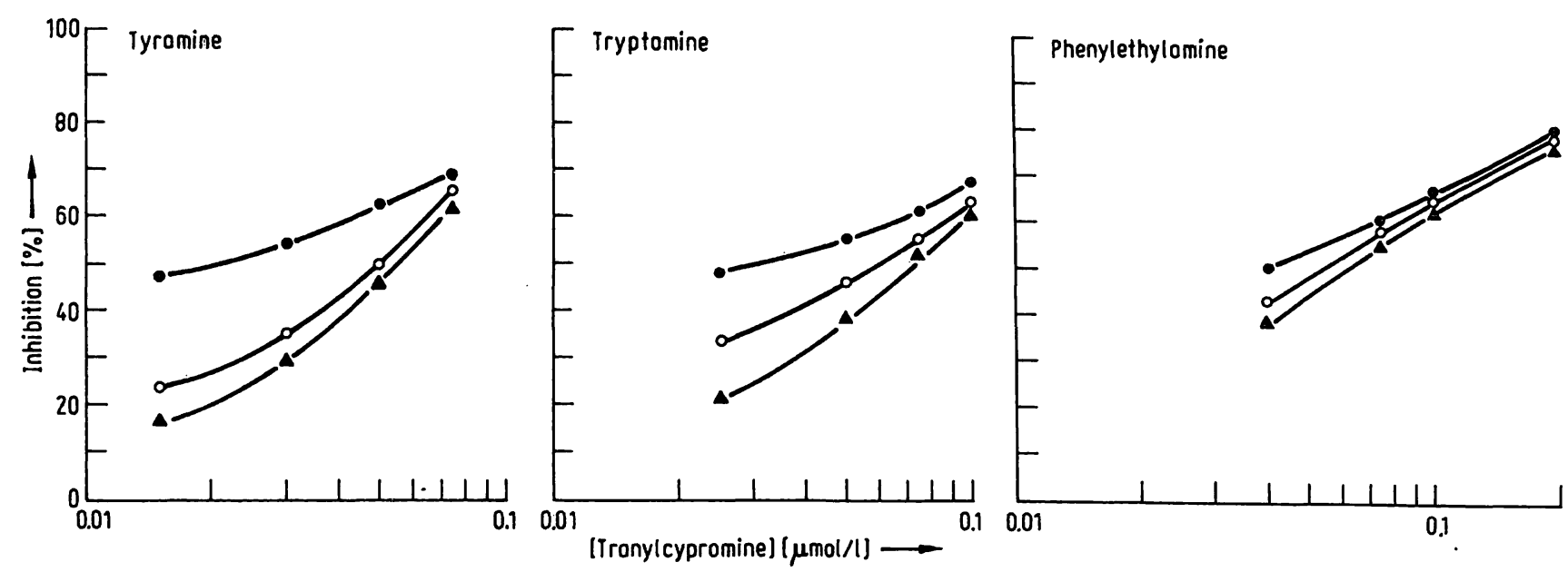

Fig. 8. The influence of amitriptyline on the inhibition of platelet monoamine oxidase by tranylcypromine, when the substrates tyramine, tryptamine and $\beta$-phenylethylamine were used. Experimental details are presented in Methods. Without amitriptyline (A-A)

Amitriptyline $1 \mu \mathrm{mol} / \mathrm{l}(\mathrm{o}-\mathrm{0})$

$10 \mu \mathrm{mol} / 1(\bullet-\bullet)$

\section{Discussion}

Experimental references to platelet monoamine oxidase activity in psychiatric patients are controversial, although similar methods have been used (7-11). The discrepancies could be explained to some extent by the fact that in most of the studies only one single substrate concentration was used. Figure 9, by means of two fictive Lineweaver-Burk plots, exemplifies why such differences are possible. The steeper line symbolizes a monoamine oxidase kinetic of platelets of psychiatric patients, the other one a kinetic from control persons. If we assume that in one laboratory the enzyme activity is measured only with one substrate at the substrate concentration " $x$ ", in a second laboratory at " $y$ ", and in a third one at " $\mathrm{z}$ ", the conclusions would be contradictory in respect to " $y$ ". The first investigators would find higher enzyme activity in patients, the second one no change, the third one a decreased activity compared to controls.

A further source for the different findings may be the procedures of isolation and preparation of platelets. It appears, that the phospholipid content of the monoamine oxidase has a marked influence on the enzzyme properties (1). Removal of monoamine oxidase from its environment by solubilisation procedures, including ultrasonic and detergent treatment of mitochondrial preparations, may result in a modification of its properties $(1,18,19)$. By treatment of purified platelet monoamine oxidase with sodium perchlorate in order to remove the phospholipids from the enzyme, a five fold increase of the Michaelis constant for phenylethylamine was observed (13).

Phenylethylamine and serotonin are among the substrates that have been studied with platelet monoamine oxidase. Some studies have reported that the platelet monoamine oxidase which is primarily type $B(12,20)$ most actively deaminated phenylethylamine, but only showed low activity for serotonin $(12,21,22)$. Our results are in agreement with these findings, but they conflict with those of Youdim et al (23) who found an enzyme activity for serotonin which was more than twice as high as the activity for phenylethylamine.

We have noticed substrate inhibition for phenylethylamine in molar concentrations as low as $10 \mu \mathrm{mol} / \mathrm{l}$. Similar results have been found in monoamine oxidase prepared from porcine brain, where inhibition was caused by a substrate concentration of about $0.5 \mathrm{mmol} / \mathrm{l}$ (24). Therefore it is necessary to elucidate the kinetic behaviour of an enzyme-catalyzed reaction before starting activity measurement with fixed substrate concentrations. It is surprising that even in recent publications on monoamine oxidase activity in platelets, phenylethylamine was used in millimolar concentrations (23).

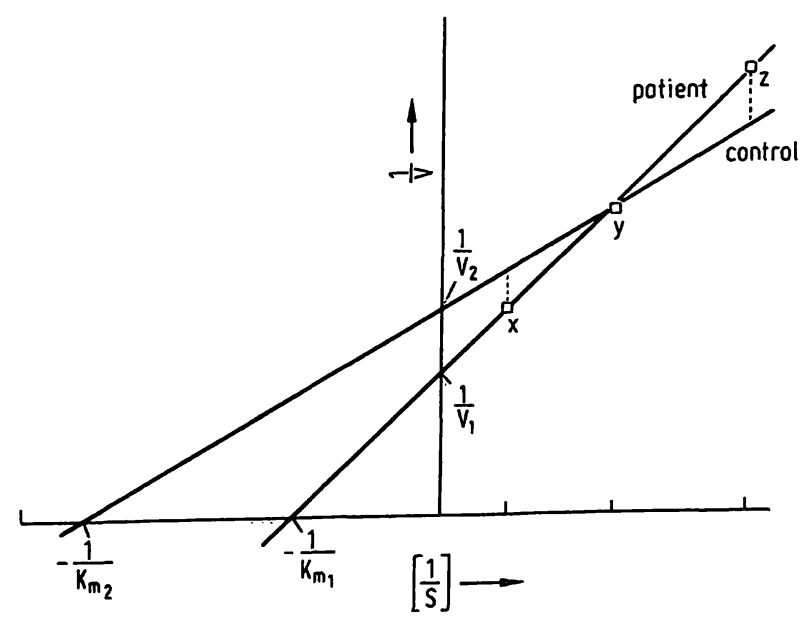

Fig. 9. Fictive Lineweaver-Burk plots of platelet monoamineoxidase activity from patients $(\square-0)$ and healthy control persons (-). 
Assuming that the affinity of the monoamine oxidase to different substrates is changed in psychiatric patients, the alteration of the enzyme could be detected by the determination of the $K_{\mathrm{m}}$ but not of the activity, measured at a single substrate concentration, which would simulate equal enzyme activity; however, a complete kinetic study might reveal great differences in $K_{\mathrm{m}}$ and $V$ values. To avoid incorrect interpretations it is necessary to examine $K_{\mathrm{m}}$ and $V$ of each platelet sample for several monoamine oxidase substrates. In addition to these constants we measured the $I_{50}$ (tranylcypromine) of each substrate with the implication that a change of the Michaelis constant may also reflect an alteration of the inhibition characteristic.

Recently it has been reported that besides the classical monoamine oxidase inhibitors other psychoactive drugs could have some influence on monoamine oxidase activity $(13,14,25,26)$. Several CNS depressants such as morphine, levallorphon, barbital, and ethanol increase the deaminating catalysis of monoamine oxidase from rat brain and bovine brain in the presence of serotonin. This effect resulted in a change of $K_{\mathrm{m}}$ and $V$. The concentrations required to be effective are about $100 \mu \mathrm{mol} / \mathrm{l}$. Also during long term lithium treatment, an increase in human platelet monoamine oxidase activity has been observed by Bockar et al (26). Tricyclic antidepressants inhibit monoamine oxidase in vitro $(13,14)$. The amitriptyline induced inhibition of platelet monoamine oxidase was most pronounced when phenylethylamine was used as substrate. The inhibition was much weaker using tryptamine or benzylamine (13).

Our results show that amitriptyline alters the $V$ and $K_{\mathrm{m}}$ providing the concentration is higher than $10 \mu \mathrm{mol} / \mathrm{l}$; the $\mathrm{I}_{\mathbf{5 0}}$, however, was considerably affected by amitriptyline at $10 \mu \mathrm{mol} / 1$. The plasma levels of amitriptyline during its therapeutic administration can be assumed to be not higher than about $1 \mu \mathrm{mol} / \mathrm{l}$ (27). Therefore, under clinical conditions tricyclic drugs like amitriptyline will have no noticeable influence on the parameters mentioned.

\section{Acknowledgement}

This study was supported by the "Deutsche Forschungsgemeinschaft".

\section{References}

1. Sandler, M. \& Youdin, M. B. H. (1974), Int. Pharmacopsychiat. 15. Lowry, O. H., Rosebrough, A. L., Jarr, A. L. \& Rosenthan, $9,27-34$.

2. Johnston, J. P. (1968), Biochem. Pharmacol. 17, 1285-1297.

3. Squires, R. F. (1972), Adv. Biochem. Psychopharmacol.5, 393-408.

4. Neff, N. H. \& Goridis, C. (1972), Adv. Biochem. Psychophaimacol. 5, 307-323.

5. Snyder, S. H. (1972), Arch. Gen. Psychiatry 27, 169-179.

6. Mosnaim, A. D., Inwang, E. E., Sugermann, J. H., de Martini, W. J. \& Sabelli, H. C. (1973), Biolog. Psychiatry 6, 235-257.

7. Murphy, D. L. \& Weiss, R. (1972), Am. J. Psychiatry 128, $35-41$.

8. Murphy, D. L., Belmaker, R. \& Wyatt, K. J. (1974), J. Psychiat. Res. 11, 221-247.

9. Nies, A., Robinson, D. S., Harris, L. S. \& Lamborn, K. R. (1974), Psychopharmacol Bulletin, Vol. 10, No. 3, 10-11.

10. Friedman, E., Shopsin, B., Sathananthan, G. \& Gershon, S. (1974), Am. J. Psychiatry 131, 1392-1394.

11. Shaskan, E. G. \& Becker, R. E. (1975), Nature, 253, $659-660$.

12. Collins, G. G. S. \& Sandler, M. (1971), Biochem. Pharmacol. 20, 289-296.

13. Edwards, D. J. \& Burns, M. O. (1974), Life Sci. 15, 2045-2058. 1

14. Roth, J. A. \& Gillis, C. N. (1974), Biochem. Pharmacol. 23, 2537-2545.

N. J. (1951), J. Biol. Chem. 193, 265-275.

16. Lineweaver, H. \& Burk, D. (1934), J. Am. Chem. Soc. 56, 658-666.

17. Dixon, M. (1953), J. Biochem. 55, 170-171.

18. Tipton, K. F. (1972), Adv. Biochem. Psychopharmacol. 5 , $11-24$.

19. Tipton, K. F., Youdim, M. B. H. \& Spires, J: P. C. (1972), Biochem. Pharmacol. 21, 2197-2204.

20. Meltzer, H. Y. \& Stahl, S. M. (1974), Res. Comm. Chem. Path. Pharmacol. 7, 419-431.

21. Murphy, D. L. \& Donnely, C. H. (1974), Adv. Biochem. Psychopharmacol. 12, 49-85.

22. Neff, N. H., Yang, H. Y. T. \& Fuentes, J. A. (1974), Adv. Biochem. Psychopharmacol. 12, 49-57.

23. Youdim, M. B. H., Woods, H. F., Mitchell, B., Graham-Smith, D. G. \& Callender, S. (1975), Clin. Sci. Mol. Med. 48, 289 -295 .

24. Williams, C. H. (1973), Biochem. Pharmacol. 23, 615-628.

25. Bellin, J. S. \& Sorrentino, G. M. (1974), Res. Comm. Chem. Path. Pharmacol. 9, 673-680.

26. Bockar, J., Roth, R. \& Heninger, G. (1974), Life Sci. 15, 2109-2118.

27. Braithwaite, R. A. \& Widdop, B. (1971), Clin. Chim. Acta $35,461-472$.

28. Honecker, H., Christ, W. \& Müller-Oerlinghausen, B. (1975), Exp. Brain Res. Suppl. to 23, 93-94.

\author{
Dr. Henning Honecker \\ Institut fur Neuropsychopharmakologie \\ der Freien Universität Berlin \\ Ulmenallee 30 \\ D-1000 Berlin 19
}

